\title{
Policy Analysis of Abortion in Indonesia: The Dynamic of State Power, Human Need and Women's Right
}

\author{
Claudia Surjadjaja
}

\begin{abstract}
A knocking at the door at midnight woke me up. I cautiously opened the door to see a haggardlooking couple with their 13-year-old daughter. They had walked five days through the wilderness of western Papua seeking help for the girl. She was two months pregnant, having been raped by her grandfather. They pleaded with my husband, an obstetrician working at the government hospital, to perform an abortion. Abortion is illegal in Indonesia and my husband faced criminal consequences had he performed the surgery. Deeply saddened, he refused them. The mother and the daughter cried and begged for help. They left us looking hurt, angry and defeated. A week later, my husband came home and explained how he had to perform an emergency hysterectomy on that young girl. She had been taken to an illicit abortionist with no formal medical training. The girl was in a terrible condition and indeed the next day she died of sepsis as a result of her injuries at the hands of the criminal abortionist. The law that tied my husband's hands with this girl killed her. The law makes no exception perform an 'elective' abortion and face prison time. My research documents the prevalent nature of this problem among Indonesia's legitimate health services providers.
\end{abstract}

Kartini is an icon of the women's rights movement in Indonesia. She died in 1904 in childbirth at the age of 25 , martyred in a cause she wrote eloquently of. More than a century later, Indonesia today still suffers one of the highest maternal mortality ratios (MMR) in the sub-region (310-370/100,000). As poor as this is, it reflects only those deaths officially linked to pregnancy. Like the young girl in Papua, death is typically not linked to her pregnancy, but simply attributed to sepsis. This spares the family social stigma and possibly criminal prosecution. Laws against abortion kill Indonesian women. What health policy and politics failure allows this? The answer to this question may fairly be described as the cause of these deaths. If one understands the cause, one is equipped to intervene and save human life.

Although practised widely, the issue of abortion brings forth more controversy than perhaps any other single health issue. Abortion is still a subject that provokes fervour and debate because it raises fundamental questions about human values. Nonetheless, radical reforms leading to general decriminalisation of abortion practices have occurred over the past 50 years, especially in the developed world. Do these successes show the way for reform in Indonesia? Perhaps not, first because Indonesia's situation is unique in the context of developing nations reforming abortion laws, and second because the abortion issue in Indonesia has been framed in the context of the ideological poles of Western democratic liberalism and fundamentalist Islamic values.

\section{Religions in Indonesia}

Religion plays a major role in life in Indonesia. Although a majority of the population is Muslim, Indonesia is not an Islamic state. The state ideology endorses belief in one supreme God. A number of different religions are practised in Indonesia, and their collective influence on the country's political, 
economical and cultural life is significant. Although Indonesia's constitution assures the right for all persons to worship according to his/her own religion, only six religions are officially recognised (Islam, Christianity, Catholicism, Buddhism, Hinduism and Confucianism). All Indonesians must choose one of these recognised religions and declare it - the declaration appears on the national ID card, which everyone is required to carry. Critics asserted it served to deepen religious divides in a country struggling to mend internal fences often defined along religious lines. Religion stirs hearts and minds in Indonesian society. Most Indonesians look to their religious leaders for answers on moral issues, including abortion. They do not consider laws of the State moral guidance, but instead expect the State to look to religion for moral guidance in making laws.

\section{The legal system in Indonesia}

The Indonesian legal system is extraordinarily complex and still evolving. Although Indonesia has more Muslims than any other country in the world, Sharia law has not been adopted as the main law in the country. This derives from the hundreds of years of Western (principally Dutch, but also British) colonial rule. The transition from the Dutch colonial legal administration into the Indonesian legal system attempted to enforce the concept of unity in diversity (uniting the vast diversity of cultures across the Indonesian archipelago) and to implement a unified legal system, but this ideal has yet to be accomplished. The effort appears to be simply adopting Western laws that are framed for a capitalist society with a high degree of individualisation. However, by implementing a massive, highly centralised bureaucratic and autocratic system of government, Indonesia bypassed the more nuanced needs of a pluralistic society and thus destroyed legal pluralism. Currently, there are three recognised legal systems in Indonesia: (1) the national law derived from Dutch colonial law (civil law), (2) Islamic law (Sharia), and (3) customary law (Hukum Adat).

This complex legal status often places Indonesian women at tremendous disadvantage - where protection may exist within the formal Western legal model, discriminators may justify their supposedly illegal actions by citing either Islamic or traditional laws (or vice versa) because local authorities may enact additional laws beside the national law. For example, in a predominantly Muslim area, local government can incorporate Sharia law in its local regulations. Customary law still exists in areas with ethnic groups living traditional non-Western and non-Islamic lives. For example, community leaders carefully consider community consensus in mediating a dispute. Thus, a person convicted for a crime may be tried and brought to justice under several systems of law depending on where he lives, his ethnicity or his religion. Among communities, Hukum Adat exerts the most profound influence on the daily lives of the members of these communities.

\section{Ambiguity and contradiction in the laws related to abortion}

Under section 346-348 of the Indonesian Criminal Code, any person performing an abortion is subject to imprisonment for five and a half years and a woman willfully inducing her own miscarriage is subject to imprisonment for up to four years. Although the Code contained no exceptions to its general prohibition on the performance of abortions, in the 1970s, an 'understanding' was reached by medical professionals, on the advice of the Chief Justice of the High Court, that abortions could be performed to preserve a woman's life or health. What soon followed that informal agreement were continuous attempts to reform the abortion law formally. These efforts were led by members of the legal and medical professions, as well as by women's organisations, to reduce morbidity and mortality associated with clandestine abortions. As a result, the draft bill of 1989 on Pregnancy Termination for Health Considerations was passed into law (Health Law No. 23/1992) in September 1992. The Health Law Article 15 verse (1) specifies that:

In the case of emergency and with the purpose of saving the life of a pregnant woman or her foetus, it is permissible to carry out certain medical procedures.

Clearly, the word 'abortion' has been avoided and the statement is also vague because it says to 'save the foetus'. The law further explains that the 'medical procedures' must be based on the guidance of a team of experts, must have the consent of the pregnant woman or of her husband or family, and must be performed by health workers with the expertise in a 'certain structure'. An explanatory note to the law specifies that the health worker must be an obstetrician/gynaecologist, that the expert team is to be multidisciplinary, and that the husband or 
family is to give consent only when the woman is unconscious or otherwise unable to give consent.

This Article 15 verse (1) contradicts other articles in the Health Law and even articles in the Criminal Code which regulate the punishment and fine. Adding more confusion, the Medical Practice Law (UU RI No. 29/2004) provides another provision for maximum sentences. Despite its ambiguity and contradictions with other laws, the 1992 Health Law itself cannot be fully implemented because of the elusiveness in its articles. The law also fails to accommodate recent medical technology, does not differentiate between juvenile and adult reproductive health issues, does not regulate health facilities, and does not describe the responsibility of local government in response to the massive tide of decentralisation of government authority and services which has occurred since the change of regime in 1998.

These legal contradictions have spawned a virtual freefor-all in viewpoints on what constitutes legally sound abortion practice. Some view any act to terminate a pregnancy as strictly illegal, while others take the view that 'menstrual regulation' (a euphemism for early abortion practice) is not considered to be illegal abortion because it accords with the Islamic view that ensoulment of the fetus does not take place until 120 days of pregnancy have passed. Some believe that abortion in the first trimester is allowed to save the woman's life, or permitted in the case of fetal deformity.

The vague legal status of abortion has also precipitated many controversies among professionals and law enforcement officials. For instance, some doctors interpret saving a woman's life as putting the woman out of the danger which could harm her not only physically but also mentally. Hence, these doctors will perform abortion in the case of rape or incest, especially in adolescents with the consent of their parents. On the other hand, law enforcement in a morally conservative context interprets the vague law literally. As a result, many doctors and also women are convicted as criminals under the criminal law and imprisoned.

\section{Abortion practice}

Although the laws on abortion in Indonesia are relatively restrictive, they are not strictly enforced. $A$ million or more Indonesian women seek termination of unwanted pregnancies each year. The clandestine nature of virtually all of these abortions, driven by social stigma, religious prohibitions and serious legal consequences, conceals the extent to which unsafe abortion causes death and illness. Witchdoctors, traditional birth attendants, nurses, midwives and even many general practitioners provide abortions but lack adequate training and their technical incompetence causes deaths from abortion complications. As stated before, only obstetricians/ gynaecologists are allowed to perform abortions under existing laws (and under some vaguely defined conditions), thus they are the only group to receive adequate training and be regarded as competent.

In Indonesia, access to maternal health services depends very much on a woman's marital status. Women who conceive out of wedlock access maternal health services only with the substantial risk of severe condemnation and social stigma. Neglect of single women's reproductive health problems is deepened by the Indonesian Population Law of 1992, Article 10: it is illegal to provide family planning services to unmarried women (a concession to religious groups in exchange for their support). Providing contraception services to unmarried women is explicitly forbidden. Thus, while abortion for married women is tacitly accepted and allowed under some interpretations of existing law, especially for women with two or more children, premarital pregnancy and abortion remain highly stigmatised and therefore extremely risky for single women. Abortion providers are highly critical of unmarried women who seek abortions, despite their willingness to carry out the procedure.

\section{The movement to legalise abortion and the change in Indonesia and global macropolitics} The history of the amendment of the 1992 Health Law is coloured by many factors from a complex macro political-economic situation, to local sociocultural and socioeconomic issues. In Indonesia, where religion is considered an essential component of social life, discussion of reproductive health inevitably has a theological dimension. Moral and religious controversies over family planning, abortion, sexual rights and other aspects of reproductive health shape the debate and the movement to liberalise abortion law in an Indonesian sociocultural context.

Since 1998, Indonesia has been in a state of constant political and economic reform. Although most of 
these changes may be considered positive by liberal democratic standards, reform has exacerbated old problems and created new ones. Chief among these is the stability of Indonesia as a republic uniting a diverse range of people across its vast archipelago. Divisions deepened and communal conflict arose in many provinces. The stability of the union of the republic was seriously challenged and the government made stabilisation and harmonisation a very high priority.

As a relatively young nation, Indonesia has tried to find her way to be more democratic. Global political changes have also played important roles in influencing successive governments. Each president and the appointed cabinet and elected parliament members have played significant roles in addressing the issue of abortion. This issue cannot be separated from Indonesia's history in the struggle to search for its identity since its independence from 350 years of Dutch colonial rule in 1945. The abortion issue weaves itself into the political texture of the nation, and this has been especially true since the fall of dictatorship and the rise of democracy.

The effort to amend the health law was started during Soeharto's presidency. In 1995, concerned people from health and women's non-governmental organisations (NGOs) conveyed the need to amend the health law to parliamentarians in the health commission. After a series of brainstorming sessions with the Ministry of Health and related ministries, professional bodies, academics and health NGOs worked to identify and list the problems - and the first draft bill was developed with the assistance of the Department of Law and Justice. Then the economic crisis of 1997-8 ripped across South-east Asia. Indonesia was particularly badly affected with the Rupiah losing 80 per cent of its value (relative to the US dollar) within just a few months. The crisis precipitated a boiling over of the long simmering discontent with the government. As the depth of the economic failure became fully realised, open hostility to the government poured on to the streets resulting in Soeharto's downfall in May 1998. This was not just a change of government but the dying gasp of an authoritarian style of governing the diverse peoples on the Indonesian archipelago that started with the arrival of the Dutch over 400 years ago. The fall of the strongly Jakarta-centric regime precipitated a strong and swift current sweeping the authority of government out to the long- disenfranchised provinces and districts. It was seen as a very high priority in order to preserve the unity of a now shaky republic having many regions bearing historic grudges against Jakarta. The fear and urgency were not unreasonable because at the time, East Timor had been lost, and Aceh, Irian Jaya and several other provinces were also agitating to break away and thus threaten the integrity of the republic. The decentralisation process was rapid and far reaching, and it laid the groundwork for more equitable relations between Jakarta and the provinces in the long term. But in the short term, because central government controls had loosened while provincial controls were not yet established, decentralisation poured fuel on the flames of the reform process. The draft health bill got lost in this transformation.

When Megawati became the first woman president, she brought hopes for many womens' rights advocates due to her promise to protect women and give more attention to women's issues. However, her cabinet appointments reflected her political debts to various political party leaders and the military, and these stymied many reforms. Megawati made constitutional reform one the priorities for her new government. She called for the establishment of a constitutional commission to consider amendments to the 1945 Constitution. As these reforms unfolded, the first bill to amend the health law was being discussed internally in parliament. At this crucial point, facing the first popular election of a president, she was defeated by Soesilo Bambang Yudhoyono and her term ended before the amendment could be considered as law. Before she left office, in 2004 Megawati endorsed a new regulation about the process/stages to make and amend bills (UU RI No. 10/2004). With the enactment of new regulation, and the change of the cabinet under the new president, the process to amend the health law had been put back to square one.

At the international level, the tragic events of 11 September 2001 started the new era of world politics and an ominous US national security strategy. The very symbol of liberal democracy suddenly exposed very sharp teeth that happened to sink into predominantly Muslim nations. Subsequently, other events around the world served to escalate tension between Muslims and the West. The cultural clash is becoming more and more entangled, seeping into the politics and attitudes of the West and of the 
Muslim world, including Indonesia. Muslims all over the world present themselves as robust defenders of Islamic values. In Indonesia - where more than 80 per cent of its population are Muslims - there is growing anti-Western sentiment. This severely affects internal reforms aimed at issues like women's reproductive health rights, which are widely perceived as rooted in Western ideologies. The global conflict colours the dispute far beyond the realm of the abortion issue itself. The conservative religious community in Indonesia exploits the issue, seeing it as secular liberalism (capitalistic/Western) pitted against Islam.

\section{Assessing the future}

Indonesia has been a party to the Committee on the Elimination of Discrimination Against Women (CEDAW) since 1984 (ratified as UU RI No. 7/1984), and this illustrates the government's political will to take issues such as violence against women seriously. In response to strong protests from a broad spectrum of women activists/organisations to government passivity in the face of incidents of sexual violence during the May 1998 riots, the government established the Indonesian National Commission on Violence Against Women on 15 July 1998, through Presidential Decree No. 181. It refers to the CEDAW Declaration. However, the laws and regulations still contain provisions that are discriminatory towards women. In practice, women remain unequal to men in terms of rights and opportunities because of a combination of traditional and cultural practices and certain laws that are contrary to the principle of equality. All of these give a glimpse of a woman's position in Indonesian society. An ongoing movement, led by women's groups, medical and legal professionals, seeks to reform the health law in accordance with the global movement to increase reproductive health services access for women in developing countries.

While waiting for the government to appoint the institutions that will draft the proposed amendment of the health law, a hardline Islamic bloc in parliament pushed to pass anti-pornography legislation (RUU APP), banning art, culture or literature that is deemed erotic or offensive to Islam. This push provoked heated debate. The bill contains provisions under its prohibitions of 'porno-action' that in effect criminalise the female body. Some of these provisions include a ban on women revealing parts of their bodies in public, including the thigh, hip, buttocks, belly button, shoulders and - either partially or wholly - breasts. Penalties include 2-10year jail terms. This anti-pornography bill has stirred society with its proposal to require women to be covered from head to toe. Proponents, invariably Islamic, cite their wish to protect women as justification. Massive demonstrations from both pro and contra forces occurred daily for months. It fiercely tore at the country's pluralistic nature, placed pressure on community diversity and diminished individual rights. The debate on this anti-pornography law has indirectly stalled the amendment process of the health law. The amendment of the health law is seen as embodying liberal values in frank opposition to fundamentalist, anti-pluralist, Islamic values. While previously the health amendment received little popular attention, it has now become a lightning rod of national debate on the unity of the country. The fact that a presidential decree is needed for the health bill to be further discussed can stall the amendment process. The executive branch seems reluctant to make a decision regarding this sensitive issue.

The way an issue is framed is very critical. It is unanimously agreed that Indonesia's MMR is too high. However, views on the cause of this high rate are widely divergent, and therefore priority and strategies for solving the problem are correspondingly divergent. There is a consensus that the high MMR is a major health problem, but there is no consensus that abortion is a major contributing factor to the high numbers. Everyone widely sees abortion as a problem, but there is no consensus on why and in what way it is a problem. There are many different proposed solutions for unsafe abortion, for example increased access to family planning, education, better economic conditions, greater control of women's reproduction through promotion of religious/moral values, and legalisation of abortion by incorporating it in the health bill.

For those who see abortion as a significant contributing factor to the high MMR, access to safe, affordable and legal abortion constitutes the solution. The strategy aims to set up legal and affordable abortion clinics, train health personnel to perform safe abortion, etc. This strategy requires incorporating safe abortion access into the health bill - the new law would serve as an umbrella under which to develop regulations, policies and practices to address it. Women's NGOs and liberal Islamic-based religious 
groups see it as a women's rights issue in terms of a woman's right not to die because of unsafe abortion and a woman's right to choose whether or not to continue a pregnancy. The women's groups, individuals in the parliament and certain academicians, who view abortion not only as a health issue but a human rights issue, offer solutions to legalise abortion - allowing every woman to decide whether she wants to continue her pregnancy or terminate it without the fear of violating the law and facing prosecution. Thus, language allowing less restrictive access to abortion somehow needs to be incorporated into the bill. The hard-line religious groups and political parties view abortion as a result of a morally corrupt society and propose a different solution to address the abortion issue.

There are clearly different perceptions about the solution for the high MMR, but everyone agrees that the health law needs to be amended although the reasons are varied. The issue now is whether legalising or at least decriminalising abortion should be incorporated in this health bill. All key actors support the amendment of the health law in general, but sharp divisions arise when confronting proposed solutions to the abortion issue.

The proponents of abortion rights view the amendment of the clause on abortion as a means of decriminalising abortion, which means increasing access to abortion with fewer legal obstacles and thus diminishing the likelihood of unsafe covert and unregulated abortion services. This does not set legalisation of abortion as the goal. If the proabortion policy advocates insist on a noncompromising legalisation of abortion, those who support the amendment of the health law in general could become defensive and veto it. Thus there is no consensus about the language in the health bill, especially those articles regarding abortion. Belonging to this group are parliament members, especially those on the health commission, and members of professional bodies, NGOs and progressive religious groups.

The opponents of abortion rights view the amendment of the clause on abortion as a means of legalising it; this is the establishment of access to abortion as a health right that cannot be denied. Hard-line religious groups and political parties belong to this group because they perceive the articles about reproductive health as a means to justify abortion. This group equates the term 'legal' with 'legitimate'. In other words, if it is legal it is morally just, or legitimate. However, in the language of law, 'legalise' carries no such meaning. It instead means to regulate and not to liberalise.

The turnover in the executive and legislative branches can also influence policy development and political will by creating a shift in priority given to reproductive health issues. The abortion issue is not a public health debate per se. Focus on the cause of the high MMR fails to acknowledge the broader context. Although prominent Islamic religious groups acknowledge that the Koran indicates 'ensoulment' occurs at about day 120 of pregnancy, there is still no consensus about the language on this topic in the health bill. That language must survive the prevailing political will at the time it goes to legislative consideration. In order to do so, it must express the over-arching aim of bringing down the unacceptable MMR rather than sharply focusing on the decriminalisation of abortion.

\section{Distinctly Indonesian}

Clearly, the Indonesian context is different in some respects and there are several reasons why the tactics used successfully in other countries would not work there. First, Indonesia has a fiercely patriotic character that has, on several occasions, prompted her to decline foreign assistance. The founding President Soekarno famously said to John F. Kennedy in a radio address, 'To Hell with your aid!' Every schoolchild in Indonesia knows this; it is engrained in the national psyche. More recently, in 1994, President Soeharto called for an abrupt and complete end to aid from the Dutch government because he did not like some of the ideological reform conditions attached to it. Donor agencies simply cannot play that card in Indonesia. Indonesia has access to adequate funds to support abortion services, but has lacked the political will to institute reforms allowing safe and legal abortion. When foreign partners participate in a reform effort they bring intellectual, economic and social resources to the table. Therefore, this independence from foreign influence in general, but on the abortion issue in particular, also creates a vacuum of alliances and power. In other words, the abortion reform movement in Indonesia generally lacks the influence on political will that foreign funding can bring. Motivated, experienced and resourced allies from the international community tend to be excluded. This 
stance of the government of Indonesia, along with a large degree of independence from aid linked to controversial reform requirements, essentially demobilises effective alliances with potentially powerful partners beyond the borders of Indonesia.

Another important distinction from other countries is Indonesia's ideological and historical context. The struggle for abortion reform in Indonesia is occurring at the juncture of three history-shaping trends: (1) new democratisation, (2) strengthening Islamic values, and (3) the framing of a global 'war' on terrorism. The first truly democratic election of a president occurred in 2004. Democratic liberalism, while certainly moving forward, is nonetheless relatively embryonic, and it is being challenged by a much older and more firmly established religious fundamentalism. Worse still, that challenge is occurring in the turbulence of the global 'war' on terrorism, where many Muslims, rightly or wrongly, perceive the West as waging a war against their religion. $A$ woman's right to safe and legal abortion has been painted as a Western ideology and agenda that aims to undermine Islamic values as a front of the war on terrorism.

Following other country examples of coalition building for reform supported by foreign agencies would lead nowhere in Indonesia. In fact, far from being engaging in overt advocacy for legal change, the international community in Indonesia must assume a distinctly low profile in supporting abortion reforms. The opponents of reform would undoubtedly cite the activism as evidence of the Western agenda against Islam. In this current political climate, even an anti-reform alliance with the United States Agency for International Development (USAID) under the current Mexico Policy would be untenable. Successful reform in Indonesia must have a distinctly Indonesian and even Islamic face. Perhaps more importantly, reform must also allow the proverbial saving of face so important in most Asian societies.

Indonesians often avoid conflict and achieve consensus with subtle ambiguities in social, economic, political and legal arenas. The decision to include abortion reform in the health bill has stirred controversy, as it sets the stage for sweeping away ambiguities and creating winners and losers in the abortion debate camps. Perhaps more importantly, the debate on abortion has emerged as a lightning rod for a much broader debate now occurring in Indonesian society - the struggle between liberal democracy and authoritarian theocracy. It is the clash between these two starkly different visions of Indonesian society that sets the stage for achieving unambiguous legislation on abortion, for better or worse.

As noted, two landmark macropolitical events set this shaky stage. First, 33 years of authoritarian secular rule ended in the wake of the East Asian Economic crisis of 1997 with the fall of the Soeharto regime in 1998. That regime actively repressed fundamentalist Islamic thinking and activity, believing it to be incompatible with a diverse republic like Indonesia. Long repressed Islamic values emerged with a vengeance. When Al-Qaeda brought down the World Trade Center towers in New York in 2001, Western and Islamic values fell into sharp divisions. In the wake of these events amendment of the health law to liberalise abortion came to be seen as an encroachment of Western ideology and incompatible with Islamic values. The amendment has come to represent a critical battlefield in the ideological war for the destiny of Indonesia.

Against this backdrop, one may begin to grasp the landscape of this ideological struggle in Indonesia. The central government and the long-wielding autocratic power from Jakarta embraced decentralisation as a political instrument to placate restive and dispossessed provinces and thus preserve the republic. Regions of strong Islamic beliefs promptly passed ordinances based on their perception of Islamic beliefs, including mandatory clothing restrictions on women, curfews on their movement and criminalising their sexual liberties. The secular central government acknowledges the threat these local ordinances pose to the republic, but they have yet to challenge a single one out of fear of provoking an even more divisive conflict. Therein lies the basis of their reluctance to deal with the abortion issue directly.

Despite these daunting challenges, the advocates of women's health in Indonesia have achieved stunning political success. Through their powerful networks of access to political decision-makers, they convinced parliament to put the health bill as a priority agenda item in the National Legislation Programme for 2005-9. This success has created the bright hope of a window of opportunity in the political context. Abortion reform may yet be achieved, despite the seemingly long macropolitical odds aligned against it. 
The challenge lies in mustering the political consensus and support without compromising it. The challenges faced by such a lobby can be summarised as follows:

1 Although it is agreed that Indonesia's MMR and unsafe abortion numbers are too high, there is no consensus that abortion is the core problem.

2 Although it is agreed that the health law needs reform, the reasons vary.

3 Because of these different views on the problem and solutions, there is no strong political will.

Each of these challenges buttresses the other. Break one and the others collapse, or fail to do so and they stand. If the law protects women who seek abortions, then women's health is acknowledged as a legal priority, and the importance of their reproductive rights (and health, and in the context of abortion, the right to life itself) supersedes political costs. All these challenges can be met with appropriate strategies. Most stakeholders can accept that too many women are dying and that there are too many clandestine abortions. In bringing together supporters and opponents of abortion reform to the negotiating table, advocates must frame the issue appropriately. For example, getting across the understanding that most women seeking abortions are married will assault the first challenge - abortion is a consequence of immoral behaviour. With the health of women as an acknowledged priority, and abortion practice de-

\section{Note}

* There are many people who have willingly or even unwittingly helped me to complete the body of work represented here. Their contributions have been direct advice or technical assistance, encouragement to persist and excel, or simply have inspired me by the shining example of their own courage and accomplishment. Those, among many others, are Ninuk Widyantoro and others at

\section{Bibiliography}

Anshor, M.U. and Ghalib, A. (2004) Figh Aborsi: Review Kitab Kasik dan Kontemporer [Figh Law of Abortion: Review on Classic and Contemporary Qor'an], Jakarta: Mitra INTI Foundation

Baramuli, M.A. (2004) 'Aspirasi DPR Untuk Amandemen UU Kesehatan' [Parliament Initiative to Amend the Health Law], paper presented in the stigmatised, the political will may be achieved. If these principles operate at the negotiating table, a window of opportunity may emerge.

\section{Conclusion}

In Indonesia today, a woman with an unwanted pregnancy faces stark choices. She can see the pregnancy through to birth and face social ostracism, loss of her family support network, especially if she is out of wedlock, and even harsh criminal punishment. If she rejects this outcome, she can only seek abortion from a clandestine provider who is likely to cause her serious injury or death. We know that far too many women make the latter choice and pay with their lives. It could be said that society and the laws of Indonesia effectively deny these women the right to live by giving them such a narrow choice.

Religious authoritarianism does not only affect the health of women, it challenges the integrity of the Republic of Indonesia and its liberal democratic future. Political and moral courage is required to face authoritarianism in all forms, especially religious. The people controlling the destiny of Indonesia with their decisions must be made to understand the weight of their actions in the larger context. The fact that Indonesia embraces liberal democratic and secular values is powerful. Indonesia forges its destiny, and the abortion reform issue will certainly spark change in arenas far beyond health. She must decide. Quo vadis, Indonesia?

the Women's Health Foundation; Aisyah Hamid Baidlowi, Tuti Lukman Sutrisno, Dr Maria Akib Baramuli and others at the House of Representatives; Dr J. Kevin Baird from ALERTAsia Foundation; Dr Susannah Mayhew from London School of Hygiene and Tropical Medicine; and Professor Richard Ashcroft from Queen Mary, Barts and the London School of Medicine and Dentistry.

seminar Recent Finding on Pregnancy Termination in Indonesia, Jakarta, Indonesia, 11 August

Bedner, A. (2001) Administrative Courts in Indonesia: A Socio-Legal Study, Leiden: Brill

Bennett, LR. (2001) 'Single Women's Experience of Premarital Pregnancy and Induced Abortion in Lombok, Eastern Indonesia', Reproductive Health Matters 9.17: 37-43 
Berer, M. (2004) 'National Laws and Unsafe Abortion: The Parameters of Change', Reproductive Health Matters 12.24 Suppl: 1-8

Berita, Berkala Jender dan Kesehatan (2001) Aborsi: Sebuah Dilema di Indonesia [Abortion: A Dilemma for Indonesia], Jakarta: Pusat Komunikasi Kesehatan Berperspektif Jender

Bowen, J.R. (2003) Islam, Law, and Equality in Indonesia: An Anthropology of Public Reasoning, Cambridge: Cambridge University Press

Burns, P. (2004) The Leiden Legacy: Concepts of Law in Indonesia, Leiden: KITLV Press

Cribb, R. (1999) 'Nation Making Indonesia', in D.K. Emmerson (ed.), Indonesia Beyond Suharto: Polity, Economy, Society Transition, New York: ME Sharpe

Departemen Kesehatan [Ministry of Health] (2003) Profil Kesehatan Reproduksi [Reproductive Health Profile], Jakarta: Depkes

Djohan, E.; Indrawasih, R.; Adenan, M.; Yudomustopo, H. and Tan M.G. (1993) 'The Attitude of Health Providers Towards Abortion in Indonesia', Reproductive Health Matters 1.2: 32-40

Drakeley, S. (2005) The History of Indonesia, Westport: Greenwood

Ebrahim, A.F.M. (1989) Abortion, Birth Control, and Surrogate Parenting: An Islamic Perspective, Indianapolis: American Trust Publications: 92

Elson, R. (2001) Suharto: A Political Biography, Cambridge: The Press Syndicate of the University of Cambridge

Firth, R. (1981) 'Spiritual Aroma: Religion and Politics', American Anthropologist, New Series 83.3: 582-601

Fox, J.J. (2004) 'Currents in Contemporary Islam in Indonesia', paper presented at Harvard Asia Vision 21, Cambridge, MA, 29 April-1 May 2004

Franck, T.M. (1997) 'Is Personal Freedom a Western Value?', American Journal of International Law 91.4: 593-627

Friend, T. (2003) Indonesian Destinies, Cambridge: Harvard University Press

Gasman, N.; Blandon, M. and Crane, B. (2006) 'Abortion, Social Inequity, and Women's Health: Obstetrician-gynecologists as Agent of Change', International Journal of Gynecology and Obstetrics 94: 310-16

Gerhardt, A.J. (1997) 'Abortion Laws into Action: Implementing Legal Reform', Initiative Reproductive Health Policy 2.1: 1-3

Grimes, D.A.; Benson, J.; Singh, S.; Romero, M.; Ganatra, B.; Okonofua, F.E. and Shah, I.H. (2006) 'Unsafe Abortion: The Preventable Pandemic', Lancet, Sexual and Reproductive Health Series 65-76
Grindle, M. and Thomas, J. (1991) Public Choices and Policy Change, Baltimore: Johns Hopkins University Press

Habibie, B.J. (2006) Detik-detik Yang Menentukan: Jalan Panjang Indonesia Menuju Demokrasi [The Decisive Moments: Indonesia's Long Road Towards Democracy], Jakarta: The Habibie Centre

Hassan, R. (1993) 'Are Human Rights Compatible with Islam? The Issue of the Rights of Women in Muslim Communities', presented at Religious and Ethical Perspective on Population Issues convened by the NGO Steering Committee at Preparation Committee II of the International Conference on Population Development, New York, 19 May

Hessini, L. (2005) 'Global Progress in Abortion Advocacy and Policy: An Assessment of the Decade Since ICPD', Reproductive Health Matters 13.25: 88-100

Hull, T.H.; Sarwono, S.W. and Widyantoro, N. (1993) 'Induced Abortion in Indonesia', Studies in Family Planning 24.4: 241-51

Irwanto, Poerwandari E.K.; Prasadja, H.; Sunarno, N.; Hardee, K.; Eggleston, E. and Hull, T. (1997) In the Shadow of Men: Reproductive Decision-Making and Women's Psychological Well-being in Indonesia, final report for the Women's Studies Project, Jakarta: Centre for Societal Development Studies Atma Jaya Catholic University and Research, Triangle Park NC: Family Health International Kingdon, J.W. (2001) 'A Model of Agenda-setting, with Applications', speech delivered at the Second Annual Quello Telecommunications Policy and Law Symposium, Washington DC, April

Kingdon, J.W. (1995) Agendas, Alternatives, and Public Policies, New York: Harper Collins College Publishers

Kommers, D.P. (1992) 'Abortion in Six Countries: A Comparative Legal Analysis', in J.D. Butler and D.F. Walbert (eds), Abortion, Medicine and the Law, New York: Facts on File

Kristanti, M. (1996) 'Kehamilan Yang Tidak Direncanakan dan Aborsi di Indonesia [Unplanned Pregnancy and Abortion in Indonesia]', Majalah Kesehatan Masyarakat Indonesia [Journal of Public Health Indonesia] 24.3: 202-5

Kritzer, H.M. (2002) Legal Systems of the World: A Political, Social, and Cultural Encyclopedia, Santa Barbara, CA: ABC-CLIO

Kitab Undang-undang Hukum Pidana [KUHP Indonesian Criminal Code Book], Official State Document 
Law No.30/2004. Concerning Regulation to Bill/Law Making Process, 22 June 2004, State Gazette No. 53 of 2004

Law No. 29/2004. Concerning Medical Practice, 6 October 2004, State Gazette No. 116 of 2004

Law No. 23/1992. Concerning Health, 17 September 1992, State Gazette No. 100 of 1992, Additional State Gazette No. 3495

Law No.10/1992. Concerning Population Development and the Development of Happy and Prosperous Families, 16 April 1992, State Gazette No. 35 of 1992

Law No. 87/1984. Concerning Convention on the Elimination of All Forms of Discrimination Against Women, 24 July 1984, State Gazette No. 29 of 1984

Maguire, D.C. (2001) Sacred Choice: The Right to Contraception and Abortion in Ten World Religions, Minneapolis: Augsburg Fortress Press

Outka, G. and Brockopp, J.E. (2002) Islamic Ethics of Life: Abortion, War and Euthanasia, Columbia: University of South Carolina Press

Perry, M.J. (2001) 'Religion, Politics and Abortion', University Detroit Mercy Law Review 79.1: 1-37

Pradono, J.; Lubis, A. and Budiarso, L.R. (2001) 'Pengguguran Yang Tidak Aman di Indonesia: SDKI 1997 [Unsafe Abortion in Indonesia: Indonesia Demography and Health Survey 1997]', Journal Epidemiologi Indonesia [Indonesian Journal of Epidemiology] 5: 14-19

Presidential Decree No. 181. Concerning the Indonesian National Commission on Violence Against Women, 15 July 1998

Rao, K.A. and Faúndes, A. (2006) 'Access to Safe Abortion Within the Limits of the Law', Best Practice and Research Clinical Obstetrics and Gynaecology 20.3: 431-2

Ricklefs, M.C. (2001) A History of Modern Indonesia Since 1200, 3rd edn, Berkeley: Stanford University Press
Roadnight, A. (2002) United States Policy Towards Indonesia in the Truman and Eisenhower Years, New York: Palgrave Macmillan

Schenker, J.G. (2000) 'Women's Reproductive Health: Monotheistic Religious Perspectives', International Journal of Gynecology and Obstetrics 70.1: 77-86

Schenker, J.G. and Eisenberg, V.H. (1997) 'Ethical Issues Relating to Reproduction Control and Women's Health', International Journal of Gynecology and Obstetrics 58: 167-76

Schwarz, A. (1999) A Nation in Waiting: Indonesia's Search for Stability, 2nd edn, Boulder: Westview Press

Senanayake, P. and De Silva, U. (2003) 'Abortion, Public Health, and Human Rights', IPPF Medical Bulletin 37.4: 1-2

Situmorang, A. (1999) 'Family Planning for Indonesian Unmarried Youth: View from Medan, North Sumatera', Development Bulletin 47: 33-5

Uddin, J.; Hadiyono, J. and Widyantoro, N. (2004) Pengetahuan, Sikap, dan Perilaku Aborsi [Knowledge, Attitude, and Practice of Abortion in Indonesia], Jakarta: Mitra INTI Foundation

Weeramantry, C.G. (1988) Islamic Jurisprudence: An International Perspective, London: Macmillan

Widyantoro, N. and Lestari, H. (2004) Penghentian Kehamilan Tak Diinginkan Secara Aman Berbasis Konseling di Indonesia, Jakarta: Mitra INTI Foundation

Yaseen, M.N. (1990) 'The Inception of Human Life in the Light of the Statement from the Holy Quran and Sunnah and the Opinion of Muslim Scholars', JIMA 22: 159-67

Zenzie, C.U. (1999) 'Indonesia's New Political Spectrum', Asian Survey 39.2: 243-64 